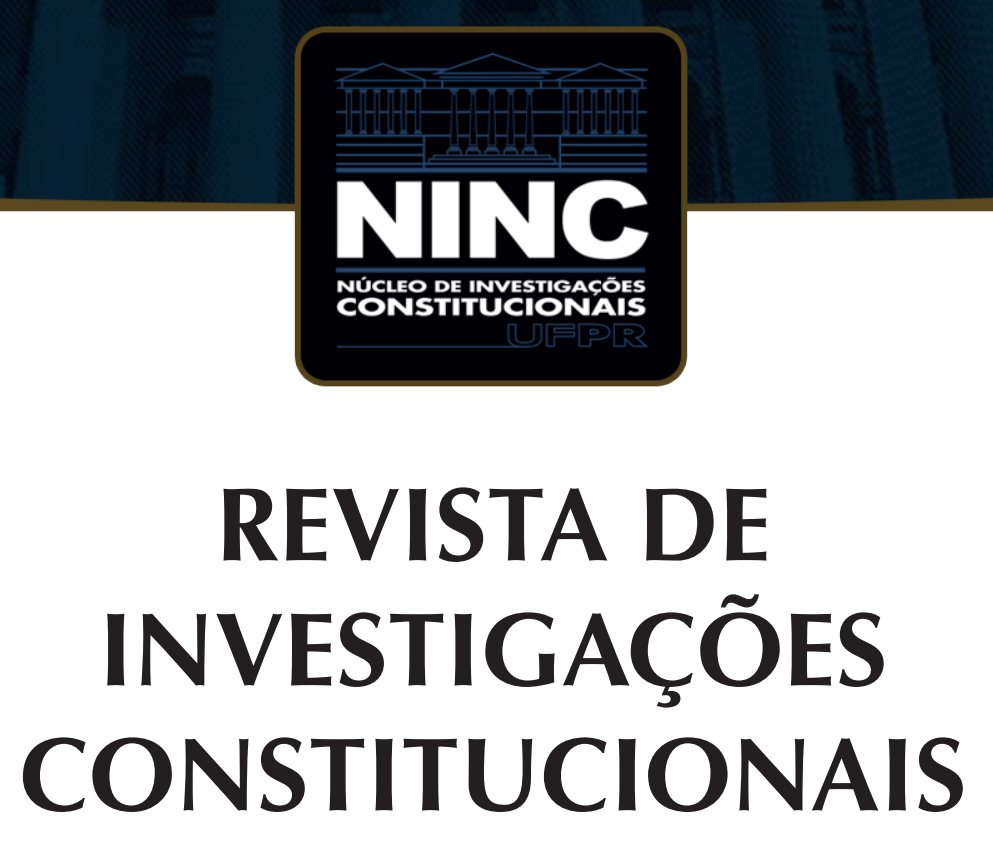

JOURNAL OF CONSTITUTIONAL RESEARCH

vol. 8 | n. 1 | janeiro/abril 2021 | ISSN 2359-5639 | Periodicidade quadrimestral Curitiba | Núcleo de Investigações Constitucionais da UFPR | www.ninc.com.br 


\title{
A superação dos precedentes na teoria dos diálogos institucionais: análise do caso da Vaquejada
}

\section{Overruling precedents in the theory of institutional dialogs: analyzing the case of "vaquejada"}

\author{
SHAYANE DO SOCORRO DE ALMEIDA DA PAIXÃO I,* \\ ' Universidade Federal do Pará (Belém, Pará, Brasil) \\ shayanepaixao@hotmail.com \\ https://orcid.org/0000-0002-5695-8758 \\ SANDOVAL ALVES DA SILVA ${ }^{1, * *}$ \\ ' Universidade Federal do Pará (Belém, Pará, Brasil) \\ sandovalsilva4@yahoo.com.br \\ https://orcid.org/0000-0002-1795-2281
}

\section{ROSALINA MOITTA PINTO DA COSTA ${ }^{1, * * *}$}

'Universidade Federal do Pará (Belém, Pará, Brasil) rosalina.costa@hotmail.com https://orcid.org/0000-0002-3673-6912

Recebido/Received: 03.01.2020 / January $3^{\text {th }}, 2020$ Aprovado/Approved: 25.02.2021 / February 25 ${ }^{\text {th }}, 2021$

\footnotetext{
Como citar esse artigo/How to cite this article: PAIXÃO, Shayane do Socorro de Almeida da; SILVA, Sandoval Alves da; COSTA, Rosalina Moitta Pinto da. A superação dos precedentes na teoria dos diálogos institucionais: análise do caso da Vaquejada. Revista de Investigações Constitucionais, Curitiba, vol. 8, n. 1, p. 275-301, jan./abr. 2021. DOI: 10.5380/rinc.v8i1.71072.

"Mestranda em Direito na Universidade Federal do Pará - UFPA (Belém-PA, Brasil), na linha de pesquisa sobre direitos fundamentais, concretização e garantias. Bolsista CAPES. Graduada em Direito pela Universidade da Amazônia (UNAMA). E-mail: shayanepaixao@hotmail.com.

"* Professor da Universidade Federal do Pará - UFPA (Belém-PA, Brasil). Doutor e mestre em Direito pela UFPA, na linha de pesquisa sobre constitucionalismo, democracia e direitos humanos. Procurador do trabalho lotado na Procuradoria Regional do Trabalho da $8^{\text {a }}$ Região. Vice Procurador Chefe da $8^{a}$ Região. Membro da International Association of Procedural Law (IAPL). Membro do Instituto Ibero Americano de Direito Processual (IIDP). Associado da Associação Norte Nordeste dos Professores de Processo (ANNEP). Ex-Coordenador Nacional da Coordenadoria Nacional de Promoção de Igualdade de Oportunidades e Eliminação da Discriminação no Trabalho (COORDIGUALDADE). E-mail: sandovalsilva4@yahoo.com.br.

"**** Professora dos cursos de graduação e pós-graduação da Universidade Federal do Pará - UFPA (Belém-PA, Brasil). Doutora em Ciências Sociais pela Pontifícia Universidade Católica de São Paulo (PUC-SP). Mestra em Direito Agrário pela UFPA. Especialista em Direito Ambiental pelo Núcleo de Meio Ambiente da UFPA (NUMA/UFPA). Especialista em Direito Civil pela Escola Superior da Magistratura do Estado do Pará (ESM/PA). Coordenadora do Grupo de Pesquisa Inovações no Processo Civil (CNPq). Mediadora Judicial Voluntária. Mediadora certificada no Cadastro Nacional de Mediadores e Conciliadores do Conselho Nacional de Justiça (CNJ/CCMJ). E-mail: rosalina.costa@hotmail.com.
} 
Resumo

Objetiva-se discutir neste trabalho a eficácia vinculante gradual dos precedentes judiciais na perspectiva da teoria dos diálogos institucionais, tomando-se como ponto de partida a análise das principais teorias que estruturam a vinculação das decisões do Supremo Tribunal Federal a partir do Código de Processo Civil de 2015. Para tanto, mostra-se como essas teorias propõem a reestruturação do Poder Judiciário com a fixação de uma Corte Suprema capaz de proferir decisões responsáveis por garantir toda a unidade do direito e a uniformidade do ordenamento jurídico e as dificuldades de superação desses precedentes. A teoria dos diálogos é exposta como um caminho intermediário e razoável para questionar a ideia de uma unidade do direito que decorre exclusivamente das decisões do Supremo Tribunal Federal, demonstrando a importância de uma construção dialogada das decisões, assim como a possibilidade de superação dos precedentes judiciais pelo Poder Legislativo, como ocorreu no caso da Vaquejada. A interação dos poderes Legislativo e Judiciário é cada vez mais necessária em um cenário de questões sociais complexas, o que concretiza a ideia de um diálogo institucional.

Palavras-chave: precedentes; diálogos; vinculação; decisões; superação.

\section{Abstract}

The objective of this paper is to discuss the gradual binding effectiveness of judicial precedents from the perspective of the theory of institutional dialogues, taking as a starting point the analysis of the main theories that structure the binding effects of Supreme Court decisions from the Brazilian Civil Procedure Code (2015). Therefore, it shows how these theories propose the restructuring of the Judiciary Power with the establishment of a Supreme Court capable of issuing decisions responsible for guaranteeing the entire unity of law and the uniformity of the legal system and the difficulties of overcoming these precedents. The theory of dialogues is exposed as an intermediate and reasonable way to question the idea of a unity of law that derives exclusively from the decisions of the Federal Supreme Court, demonstrating the importance of a dialogued construction of decisions, as well as the possibility of overcoming judicial precedents by the Legislative Power, as in the case of Vaquejada. The interaction of the Legislative and Judiciary powers is increasingly necessary in a scenario of complex social issues, which materializes the idea of an institutional dialogue.

Keywords: precedents; dialogs; binding; decisions; overruling.

\section{SUMÁRIO}

1. Introdução; 2. Precedentes no Brasil: a vinculação no CPC/2015; 3. O STF e o dilema da última palavra sobre a Constituição; 4. A dificuldade de superação dos precedentes e o papel do Poder Legislativo; 5. Análise do caso da Vaquejada à luz da teoria dos diálogos constitucionais; 6. Conclusão; 7. Referências.

\section{INTRODUÇÃO}

Este trabalho objetiva analisar a teoria dos precedentes vinculantes sob a ótica da teoria dos diálogos institucionais. Tal correlação foi feita para que se possa questionar, sobretudo, o papel do Supremo Tribunal Federal (STF) como o detentor da última palavra sobre a interpretação da Constituição e, assim, analisar se a vinculatividade dos precedentes, com base em um critério institucional ou de autoridade, como defende parte da doutrina processual, é suficiente para garantir a segurança jurídica, a unidade e a racionalidade das decisões judiciais.

Portanto, na seção 2, busca-se demonstrar quais as principais correntes sobre a eficácia vinculante dos precedentes e de que maneira a defendem. Na seção 3, a teoria dos diálogos aparece como um importante ponto de reflexão para as concepções que sustentam a vinculatividade das decisões do Supremo Tribunal Federal, demonstrando 
que, embora tais decisões tenham o condão de garantir a unidade do direito, a possibilidade de interação com o Poder Legislativo garante uma gradual segurança e uma estabilidade jurídicas, por meio da participação e do ajuste do dinamismo deliberativo entre esses poderes, em vez de fixar o STF como detentor da última palavra sobre a Constituição.

Na seção 4, procura-se ressaltar as dificuldades enfrentadas para superar os precedentes firmados pelo STF, a importância da teoria dos diálogos institucionais e a possibilidade dessa superação pelo Poder Legislativo.

Por fim, na seção 5, mostra-se que há a possibilidade de superação dos precedentes pelo Poder Legislativo, analisando-se o caso da Vaquejada, em que houve essa superação, o que nos permite inferir que a segurança jurídica e a racionalidade do ordenamento jurídico não se restringem aos precedentes firmados pelo STF, mas também dependem do entendimento firmado pelo Legislativo em um modelo que se entende dialógico e não adversarial.

\section{PRECEDENTES NO BRASIL: A VINCULAÇÃO NO CPC/2015}

A teoria dos precedentes judiciais aceita inúmeras análises, em muitos pontos diametralmente divergentes, comportando desde aqueles que defendem a inconstitucionalidade de um sistema de precedentes vinculantes no Brasil ${ }^{1}$, até aqueles que negam a existência de um sistema de precedentes ${ }^{2}$ no ordenamento jurídico. É certo, contudo, que a defesa da vinculatividade está atrelada à tentativa de diminuição da irracionalidade decisória, bem como ao empenho em assegurar uma gradual segurança jurídica aos jurisdicionados.

Não obstante essa problemática tão complexa e a existência de tantas fontes interdisciplinares, as críticas sustentam-se na restrita ideia da delegação da tarefa de uniformidade decisória às cortes superiores, sobretudo quando se pensa na reestruturação do Poder Judiciário, como propõe parte da doutrina ${ }^{3}$. Nesse caso, imaginar que caberá à Suprema Corte o dever de dar unidade ao direito por meio de suas decisões, as quais serão todas obrigatoriamente vinculantes, é pensar em uma teoria de precedentes que desconsidera a realidade fática desse órgão do Poder Judiciário e ignorar o fundamento e a característica deliberativa da democracia brasileira.

\footnotetext{
Nesse sentido, entendem Nelson Nery Junior e Rosa Maria de Andrade Nery na obra NERY JUNIOR, Nelson; NERY, Rosa Maria de Andrade. Comentários ao Código de Processo Civil. São Paulo: Revista dos Tribunais, 2015.

2 Assim defende Lenio Luiz Streck, entre outros escritos, no livro STRECK, Lenio Luiz. Precedentes judiciais e hermenêutica: o sentido da vinculação no CPC/2015. Salvador: Juspodivim, 2018.

3 Tese defendida por Daniel Mitidiero em sua obra MITIDIERO, Daniel. Precedentes: da persuasão à vinculação. São Paulo: Revista dos Tribunais, 2016 e por Luiz Guilherme Marinoni em seu livro MARINONI, Luiz Guilherme. Precedentes obrigatórios. 5. ed. rev., atual. e ampl. São Paulo: Revista dos Tribunais, 2016.
} 
Outorgar unicamente ao Supremo Tribunal Federal, enquanto instituição, o papel de garantir a segurança jurídica, a racionalidade e a unidade do ordenamento jurídico por meios estritamente formais pode ser uma prática que delega à Suprema Corte um ônus que talvez ela não possa sustentar, principalmente quando se tem revelada a sua realidade decisória. Não é à toa que os diversos estudos a respeito da deliberação no Supremo Tribunal ${ }^{4}$ são cada vez mais necessários para mostrar uma realidade que pode representar, muitas vezes, os ministros como verdadeiras "ilhas decisórias" ${ }^{\text {. }}$.

É certo que, na própria teoria de Dworkin, a ideia de integridade resulta de decisões que consideram não apenas os julgados proferidos anteriormente, mas, na construção e na busca de uma melhor resposta, o juiz deve analisar o ordenamento jurídico como um todo íntegro, do qual poderá extrair o que seria a "única resposta correta"

Isso é para que se possa entender que a proposta de vinculação de toda decisão do Supremo Tribunal Federal feita por aqueles que julgam que a vinculatividade dos julgados deve-se exclusivamente a um critério de autoridade - e, portanto, quem teria autoridade para dar unidade ao direito por meio de precedentes é a Suprema Corte encontra inúmeros desafios para se concretizar, principalmente quando se analisa a realidade decisória do STF. Inicialmente, mostrar-se-á um panorama das teorias que defendem a eficácia vinculante dos precedentes para, posteriormente, analisá-la à luz da teoria dos diálogos.

Nesse sentido, a atribuição de eficácia vinculante aos precedentes judiciais é apontada, por parte da doutrina, como uma solução para a uniformização do direito, gerando segurança jurídica aos jurisdicionados. Para alcançar os objetivos de estabilidade, uniformidade, integridade e coerência, o Código de Processo Civil (CPC) de 2015 disciplinou, em seu artigo 927, meios de garantir que as decisões anteriores sejam seguidas, dando-se previsibilidade aos julgamentos.

\footnotetext{
4 Para um maior aprofundamento a respeito do tema, sugerem-se os seguintes trabalhos: VOJVODIC, Adriana de Moraes; MACHADO, Ana Mara França; COSTA, Evorah Lusci. Escrevendo um romance, primeiro capítulo: precedentes e processo decisório no STF. Revista Direito GV, São Paulo, v. 5, n. 1, pp. 21-44, jan./jun. 2009. p. 36; SILVA, Virgílio Afonso da. "Um voto qualquer?" O papel do ministro relator na deliberação no Supremo Tribunal Federal. Revista Estudos Institucionais, Rio de Janeiro, v. 1, n. 1, pp. 180-200, 2015; SILVA, Virgílio Afonso da. Do We Deliberate? If So, How? European Journal of Legal Studies, Florence, v. 9, n. 2, pp. 209-240, 2017.

5 Não é objetivo deste texto debater a prática deliberativa no Supremo Tribunal Federal, esclarece-se, porém, que a imagem das "ilhas decisórias" ou ainda do Supremo Tribunal Federal formado por "11 ilhas decisórias" é utilizada para demonstrar o isolamento dos julgadores que integram um órgão colegiado durante o processo decisório. Para um maior aprofundamento desse tema, ver: KLAFKE, Guilherme Forma; PRETZEL, Bruna Romano. Processo decisório no Supremo Tribunal Federal: aprofundando o diagnóstico das onze ilhas. Revista de Estudos Empíricos em Direito, [s.I.], v. 1, n. 1, p. 89-104, jan. 2013.

6 A proposta hermenêutica do direito como integridade desenvolvida por Dworkin seria apta a resolver os casos do direito a partir de uma ideia de construção interpretativa. Assim, a única resposta correta decorreria da correta interpretação das normas jurídicas, as quais determinariam um só resultado, considerando a coerência narrativa dentro de uma história das práticas jurídicas (VERBICARO, Loiane Prado. Judicialização da política, ativismo e discricionariedade judicial. 2. ed. rev. e ampl. Rio de Janeiro: Lumen Juris, 2019. p. 365).
} 
Diante disso, Aurélio Viana e Dierle Nunes, citando Ronaldo Cramer, apontam a existência de pelo menos cinco correntes doutrinárias que tratam sobre o precedente judicial no CPC/2015, incluindo quem não enxerga no Código um sistema de precedentes ${ }^{7}$.

Uma primeira corrente entende que o artigo 927 do CPC/2015 contém um rol de precedentes vinculantes, a partir de um critério prioritariamente semântico. Fazem parte dessa corrente autores como Fredie Didier ${ }^{8}$ e Hermes Zaneti Junior ${ }^{9}$. A segunda corrente defende a inexistência de precedentes vinculantes no artigo 927 do CPC/2015, sendo vinculantes, de fato, apenas aqueles acobertados pela proteção da reclamação constitucional. Já a terceira corrente considera que o artigo 927 do CPC/2015 não poderia atribuir força vinculante aos precedentes, podendo exigir apenas que os tribunais observem os precedentes, apesar de reconhecer a força vinculante de cada um dos "precedentes" - corrente a que se filia Alexandre Freitas Câmara10. A quarta corrente prega a inconstitucionalidade da vinculatividade dos precedentes do artigo 927 do CPC/2015, porque só à Constituição cabe agasalhar outras hipóteses de vinculatividade, como ocorre com as decisões em controle direto de constitucionalidade e súmulas vinculantes. Podem ser identificados nessa corrente os autores Nelson Nery Junior e Rosa Maria de Andrade Nery ${ }^{11}$. A quinta e última corrente não se satisfaz com o rol do artigo 927, assumindo que quaisquer decisões emanadas das cortes supremas são passíveis de serem consideradas precedentes obrigatórios (ou melhor, vinculantes), decorrendo da autoridade das cortes a sua vinculatividade, estando nessa corrente os autores Luiz Guilherme Marinoni, Sérgio Cruz Arenhart e Daniel Mitidiero ${ }^{12}$.

Aurélio Viana e Dierle Nunes mencionam mais uma corrente ${ }^{13}$, a qual sustenta a impossibilidade de se falar em precedentes no CPC/2015 e tem como representantes Lenio Luiz Streck e Georges Abboud. Para esses autores, teríamos no CPC/2015 "um

\footnotetext{
VIANA, Aurélio; NUNES, Dierle. Precedentes: a mutação do ônus argumentativo. Rio de Janeiro: Forense, 2018. p. 215.

8 DIDIER JR., Fredie. Sistema brasileiro de precedentes judiciais obrigatórios e os deveres institucionais dos tribunais: uniformidade, estabilidade, integridade e coerência da jurisprudência. In: DIDIER JR., Fredie; CUNHA, Leonardo Carneiro da; ATAÍDE JR.; MACÊDO, Lucas Buril de. Precedentes. Salvador: Juspodivm, 2015. p. 383397.

9 ZANETI JR., Hermes. O valor vinculante dos precedentes: teoria dos precedentes normativos formalmente vinculantes. 4. ed. rev., atual e ampl. Salvador: Juspodivm, 2019.

10 CÂMARA, Alexandre Freitas. Levando os padrões decisórios a sério. São Paulo: Atlas, 2018.

11 NERY JUNIOR, Nelson; NERY, Rosa Maria de Andrade. Comentários ao Código de Processo Civil. São Paulo: Revista dos Tribunais, 2015.

12 MARINONI, Luiz Guilherme; ARENHART, Sérgio Cruz; MITIDIERO, Daniel. Novo Curso de Processo Civil. Vol. 1. 4. ed. São Paulo: Revista dos Tribunais, 2019.

13 Viana e Dierle discordam, aqui, da divisão feita por Ronaldo Cramer que colocou Lenio Streck e o próprio Dierle como integrantes da primeira corrente.
} 
sistema de vinculação jurisprudencial e não de precedentes" ${ }^{\prime 14}$, com o reconhecimento de uma influência dworkiniana no tocante à proposta de integridade.

Absorvidas as profundas e importantes críticas, a última corrente deve ser analisada de maneira moderada, pois corre-se o risco de desconsiderar por completo o vultoso ganho do CPC/2015, no que diz respeito à tentativa de criar um sistema jurídico mais estável, íntegro e coerente de decisões judiciais. Desconhecer essa tentativa por meio do rechaço total de um sistema de precedentes no Brasil não contribui para o avanço do ordenamento jurídico brasileiro. Expõem Viana e Dierle que "Por óbvio, negar a existência do precedente no Brasil não representa o automático abate das técnicas trazidas pelo Código, e, por essa razão, o sistema tornar-se-á ainda mais perverso"15.

Podem-se citar, ainda, autores que entendem que, ao invés de uma vinculação absoluta, os precedentes, seja no sistema de civil law, seja no sistema de common law, apresentam uma variada gradação de sua força normativa, não dependendo necessariamente das circunstâncias relacionadas com a exigência de uma vinculação formal legal ou constitucional ${ }^{16}$.

Assim, vale registrar primeiramente o entendimento de que se deve reconhecer que um sistema de precedentes tende a contribuir para o desenvolvimento tanto de técnicas processuais, quanto de teorias aptas a diminuir as barreiras que circundam o direito jurisprudencial, amoldando-se ao direito democrático ${ }^{17}$.

Aponta-se, também, que a eficácia vinculante dos precedentes, da forma defendida pela primeira e pela terceira correntes, encontra obstáculos grandiosos para se concretizar, sendo alguns deles a atuação prospectiva da Corte e a definição da ratio decidendi, a prática deliberativa do Supremo Tribunal Federal e a dispersão jurisprudencial. Embora o objetivo seja garantir a segurança jurídica a partir da vinculação e da obrigatoriedade de seguir os precedentes, questiona-se se tal proposição é concretizável da maneira como os autores a concebem.

Far-se-á, desse modo, a exposição das proposições de Mitidiero, Marinoni e Zaneti e, posteriormente, em tópico seguinte, apontar-se-ão alguns desafios que devem enfrentar essas teorias, sobretudo, como mostrará o penúltimo capítulo, quanto à superação de precedentes por meio da teoria dialógica no Supremo Tribunal Federal, questionando-se se o padrão proposto consegue cumprir o propósito de garantir a segurança jurídica.

14 VIANA, Aurélio; NUNES, Dierle. Precedentes: a mutação do ônus argumentativo. Rio de Janeiro: Forense, 2018. p. 217.

15 VIANA, Aurélio; NUNES, Dierle. Precedentes: a mutação do ônus argumentativo. Rio de Janeiro: Forense, 2018. p. 222.

16 Essa é a tese defendida em: MAGALHÃES, Breno Baía; SILVA, Sandoval Alves da. O grau de vinculação dos precedentes à luz do STF: o efeito vinculante é absoluto? In: ANJOS FILHO, Robério Nunes dos (Org). Direitos humanos e direitos fundamentais: diálogos contemporâneos. Salvador: Juspodivm, 2013. p. 58-85.

17 VIANA, Aurélio; NUNES, Dierle. Precedentes: a mutação do ônus argumentativo. Rio de Janeiro: Forense, 2018. p. 221. 
Mitidiero defende a reestruturação do Poder Judiciário em cortes de precedentes - também conhecidas como cortes supremas -, às quais caberia a outorga da interpretação prospectiva e a unidade do direito mediante a formação de precedentes. Segundo o autor, essas cortes não deveriam atuar para conhecer de cada um dos casos concretos decididos pelas cortes de justiça a fim de uniformizar a aplicação do direito. Portanto, não teriam como função exercer controle retrospectivo sobre as cortes de justiça. A sua função seria, de outro modo, atuar a fim de guiar as futuras decisões das cortes de justiça, dos juízes a elas vinculados, da Administração Pública e o comportamento de toda a sociedade civil. "Vale dizer: devem atuar de forma prospectiva, outorgando unidade ao direito mediante a sua adequada interpretação" ${ }^{18}$. O objetivo das cortes de precedentes seria, então, atingir essa finalidade.

Ainda segundo Mitidiero, o Novo Código de Processo Civil percebeu a necessidade de reconstrução do sistema judiciário, de modo que confere ao Supremo Tribunal Federal e ao Superior Tribunal de Justiça (STJ) a possibilidade de analisar a questão recursal mesmo que tenha havido desistência recursal (CPC/2015, art. 998, parágrafo único) e de conhecer recursos desconsiderando vícios formais (CPC/2015, art. 1029, § 3. ${ }^{\circ}$ ), ao permitir o seu amplo debate (CPC/2015, art. 1038) e ao vincular os órgãos jurisdicionais horizontal e verticalmente às razões dos julgados (CPC/2015, art. 927, art. 1039 e art. 1040). Logo, "o Novo Código deixou claro que o caso concreto levado à apreciação é apenas um pretexto para que essas Cortes possam dar unidade ao Direito"19.

Assim, aduz o autor, cabe ao Supremo Tribunal Federal e ao Superior Tribunal de Justiça o dever de dar unidade ao direito, de modo que, "A partir da existência de precedentes constitucionais e de precedentes federais, os Tribunais Regionais Federais e os Tribunais de Justiça têm o dever de controlar a uniforme aplicação desses precedentes"20.

A formação de precedentes, nesse caso, terá como fator único o caráter institucional ou de autoridade da Corte que proferiu a decisão. Assim, o precedente só poderia advir do STJ ou do STF, sem considerar as razões que o formam, sendo pouco relevante o conteúdo da decisão e sendo o precedente judicial fonte primária do Direito, cuja eficácia vinculante não decorre nem do costume judicial e da doutrina, nem da congruência social da razões invocadas e muito menos de norma constitucional legal que assim o determine, "mas da força institucionalizante da interpretação jurisdicional, isto é, da força institucional como função básica do Estado"21.

Mitidiero sustenta, ainda, a tese de que a definição sobre a ratio decidendi cabe à Corte Suprema, a qual decidirá não apenas o caso, mas também a sua interpretação

18 MITIDIERO, Daniel. Precedentes: da persuasão à vinculação. São Paulo: Revista dos Tribunais, 2016. p. 91.

19 MITIDIERO, Daniel. Precedentes: da persuasão à vinculação. São Paulo: Revista dos Tribunais, 2016. p. 92.

20 MITIDIERO, Daniel. Precedentes: da persuasão à vinculação. São Paulo: Revista dos Tribunais, 2016. p. 92.

21 MITIDIERO, Daniel. Precedentes: da persuasão à vinculação. São Paulo: Revista dos Tribunais, 2016. p. 99. 
sobre o que deve ser entendido como ratio ${ }^{22}$. Caberia às cortes supremas - também chamadas "cortes de precedentes" pelo autor -um papel não só retrospectivo, mas também prospectivo sobre os casos julgados a fim de uniformizar a aplicação do direito, devendo atuar para guiar as futuras decisões dos demais tribunais e juízes a elas vinculados, além da Administração Pública e o comportamento de toda a sociedade civil. Esse seria o papel prospectivo, capaz de dar unidade ao direito mediante a sua adequada interpretação, garantindo a igualdade e a segurança jurídica ${ }^{23}$.

Marinoni, por sua vez, na mesma linha dos precedentes obrigatórios (ou melhor, vinculantes), defende também a vinculatividade de todas as decisões do STF, a partir da atribuição de poder às cortes supremas para que, ao julgar casos, possam atribuir efeito vinculante aos principais motivos das decisões (ratio decidendi ${ }^{24}$ ). $\mathrm{O}$ autor é claro em defender que, no controle difuso, mesmo a coisa julgada não tendo efeito erga omnes, é necessário dar força aos motivos determinantes ou à ratio decidendi da decisão, "evitando-se a sua desconsideração pelos demais órgãos judiciários", e impedindo-os de negar os motivos determinantes da decisão ${ }^{25}$.

Assim, tanto Marinoni quanto Mitidiero atribuem função específica às cortes supremas, que é a de dar unidade ao direito a partir de suas decisões, as quais vincularão todas as demais instâncias do Poder Judiciário, sendo de pleno conhecimento, inclusive, de todos os cidadãos ${ }^{26}$.

Esse amplo conhecimento é fundamental, porque possibilitaria tanto ao cidadão quanto ao advogado, e principalmente a este último, avaliar a possibilidade de ajuizar ou não uma ação nos casos em que a pretensão do autor amoldar-se a um precedente obrigatório ou em que não houver precedente contrário à pretensão ${ }^{27}$.

Zaneti, assim como Marinoni e Mitidiero, defende a existência das cortes de vértice ou de precedentes, que assumiriam a interpretação e a uniformização do direito, acrescentando que seriam, também, capazes de dar racionalidade ao ordenamento jurídico por meio de uma teoria da interpretação realista, moderada e responsável ${ }^{28}$.

\footnotetext{
22 VIANA, Aurélio; NUNES, Dierle. Precedentes: a mutação do ônus argumentativo. Rio de Janeiro: Forense, 2018. p. 255.

23 MITIDIERO, Daniel. Precedentes: da persuasão à vinculação. São Paulo: Revista dos Tribunais, 2016. p. 91.

24 VIANA, Aurélio; NUNES, Dierle. Precedentes: a mutação do ônus argumentativo. Rio de Janeiro: Forense, 2018. p. 237

25 MARINONI, Luiz Guilherme. Precedentes obrigatórios. 5. ed. rev., atual. e ampl. São Paulo: Revista dos Tribunais, 2016. p. 298.

26 VIANA, Aurélio; NUNES, Dierle. Precedentes: a mutação do ônus argumentativo. Rio de Janeiro: Forense, 2018. p. 237.

27 VIANA, Aurélio; NUNES, Dierle. Precedentes: a mutação do ônus argumentativo. Rio de Janeiro: Forense, 2018. p. 238.

28 ZANETI JR., Hermes. O valor vinculante dos precedentes: teoria dos precedentes normativos formalmente vinculantes. 4. ed. rev., atual e ampl. Salvador: Juspodivm, 2019. p. 427.
} 
O autor defende que uma teoria dos precedentes é uma teoria para cortes supremas, por dois motivos: primeiro, porque as cortes supremas são as principais destinatárias de uma teoria dos precedentes por serem as cortes de vértice e delas depender a uniformidade da interpretação do direito; segundo, porque as próprias cortes supremas devem vincular-se aos seus precedentes do ponto de vista do ônus argumentativo para afastar a aplicação de um precedente ou superar um precedente antigo na aplicação atual ${ }^{29}$.

A racionalidade do ordenamento jurídico estaria intimamente ligada à função das cortes de vértice, das cortes supremas, e à correta aplicação dos precedentes, pois o modelo de precedentes será racional "porque completa o círculo de interpretação jurídica, propondo um ulterior fechamento do discurso jurídico por uma metodologia de controle de sua aplicação"30. As cortes teriam o papel não só de fixar precedentes, mas também de controlar a sua aplicação, de maneira que o autor discorda das teses que reconhecem como precedentes apenas aqueles emanados de supremas cortes, defendendo, diferentemente, que "serão precedentes mesmo as decisões que não forem de Cortes Supremas, desde que, por evidente, limitem-se à sua esfera de influência formal e, portanto, respeitem as decisões de instâncias formalmente superiores ${ }^{31 "}$.

Esse respeito às decisões formalmente superiores representa a vinculação formal, de modo que um julgamento que não respeita um precedente vinculante com relevância institucional não pode ser considerado correto ${ }^{32}$. Assim, "vinculação formal será sinônimo de vinculação de iure e implicará o reconhecimento dos precedentes como fonte normativa primária formal, independentemente do seu conteúdo"33, não se confundindo com o conceito de jurisprudência ou de decisão.

Zaneti propõe que a vinculação dos precedentes seja classificada em três graus: precedentes normativos vinculantes, precedentes normativos formalmente vinculantes (de iure) e precedentes normativos formalmente vinculantes fortes (de iure). No primeiro, a vinculatividade é compreendida a partir da exigência de argumentação racional no processo de interpretação, independente de lei formal, sendo a aplicação dos casos-precedentes tanto horizontal quanto vertical. No segundo, há uma obrigatoriedade formal de levar os casos-precedentes em consideração, sendo as decisões

29 ZANETI JR., Hermes. O valor vinculante dos precedentes: teoria dos precedentes normativos formalmente vinculantes. 4. ed. rev., atual e ampl. Salvador: Juspodivm, 2019. p. 411.

30 ZANETI JR., Hermes. O valor vinculante dos precedentes: teoria dos precedentes normativos formalmente vinculantes. 4. ed. rev., atual e ampl. Salvador: Juspodivm, 2019. p. 355.

31 ZANETI JR., Hermes. O valor vinculante dos precedentes: teoria dos precedentes normativos formalmente vinculantes. 4. ed. rev., atual e ampl. Salvador: Juspodivm, 2019. p. 404.

32 ZANETI JR., Hermes. O valor vinculante dos precedentes: teoria dos precedentes normativos formalmente vinculantes. 4. ed. rev., atual e ampl. Salvador: Juspodivm, 2019. p. 344.

33 ZANETI JR., Hermes. O valor vinculante dos precedentes: teoria dos precedentes normativos formalmente vinculantes. 4. ed. rev., atual e ampl. Salvador: Juspodivm, 2019. p. 344. 
passíveis de impugnação por via recursal no caso de não seguirem o precedente. Por fim, no terceiro, a vinculatividade é também prevista em lei, mas possibilita a impugnação por via autônoma diretamente nos tribunais superiores, quando as decisões não respeitarem a autoridade do precedente ${ }^{34}$.

Portanto, para o autor, a"força normativa dos precedentes prescinde de vinculação formal", e o reconhecimento formal pela lei dessa força normativa dos precedentes "é um passo decisivo no processo civilizatório jurídico"35, sendo fundamental que sejam normativos e vinculantes independentemente do seu conteúdo e da bondade de suas razões ${ }^{36}$.

Nesse contexto, propõe-se, à luz da teoria dos diálogos institucionais, uma nova perspectiva quanto à superação dos precedentes judiciais, porque a conexão entre a evolução do processo civilizatório e a vinculação dos precedentes do Supremo Tribunal Federal pode ser contestada com base na ideia deliberativa das práticas decisórias, cuja finalidade é permitir que a construção de respostas mais coerentes e gradualmente estáveis para os problemas seja feita de modo mais democrático e efetivamente participativo, sendo a interação entre o Poder Legislativo e Poder Judiciário uma concretização da democracia como participação.

Esse é o objetivo da teoria dialógica, ao demonstrar que a interação entre os poderes tende a fortalecer tanto o papel preponderantemente democrático do Legislativo (input), quanto o papel de garantia dos direitos fundamentais pelo Judiciário. Essas tarefas não devem ser vistas como estanques, mas dialógicas e graduais e, portanto, mais aptas à sociedade contemporânea e seus complexos problemas.

\section{O STF E O DILEMA DA ÚLTIMA PALAVRA SOBRE A CONSTITUI- ÇÃO}

As propostas apresentadas para a formação e a aplicação de precedentes vinculantes, sobretudo a partir das decisões proferidas pelo Supremo Tribunal Federal, visam garantir uma maior estabilidade nos posicionamentos jurisprudenciais do Poder Judiciário. Assim, ao se idealizar um sistema de precedentes apto a garantir segurança jurídica ${ }^{37}$ mediante decisões mais uniformes e, portanto, capaz de dar unidade ao di-

\footnotetext{
34 ZANETI JR., Hermes. O valor vinculante dos precedentes: teoria dos precedentes normativos formalmente vinculantes. 4. ed. rev., atual e ampl. Salvador: Juspodivm, 2019. p. 346.

35 ZANETI JR., Hermes. O valor vinculante dos precedentes: teoria dos precedentes normativos formalmente vinculantes. 4. ed. rev., atual e ampl. Salvador: Juspodivm, 2019. p. 347.

36 ZANETI JR., Hermes. O valor vinculante dos precedentes: teoria dos precedentes normativos formalmente vinculantes. 4. ed. rev., atual e ampl. Salvador: Juspodivm, 2019. p. 431.

37 Essa ideia é exposta por Oscar Vilhena Vieira: "Para alguns analistas, o fortalecimento da autoridade dos tribunais tem sido uma conseqüência imediata da expansão do sistema de mercado, em plano global. Aos olhos dos investidores, os tribunais constituiriam um meio mais confiável para garantir a segurança jurídica, estabilidade e previsibilidade do que legisladores democráticos, premidos por demandas 'populistas' e
} 
reito, está-se diante de uma corrente que aposta suas "fichas" no papel que o Supremo Tribunal Federal pode desempenhar como "guardião da Constituição" ${ }^{38}$.

Nesse sentido, é fundamental rever a função do STF como "guardião da Constituição", a fim de verificar a sua tarefa com base na ideia de interação deliberativa ${ }^{39}$, o que significa dizer que o modelo de separação de poderes ${ }^{40}$ precisa ter potencial epistêmico, segundo o qual "Cada poder possui ônus argumentativos que, se não atendidos, autorizam a reação do outro"41. Assim, quando se analisam os precedentes judiciais do Supremo Tribunal Federal, é importante observar que se trata de decisões que permitem uma interpretação sobre a Constituição, mas que não devem ser vistas como a "palavra final", em razão da possibilidade de superação desse entendimento, sobretudo pelo Poder Legislativo, como se verá no próximo tópico.

A ideia da última palavra ou palavra final é importante nos casos em que se deve resolver uma controvérsia, com uma decisão coletiva que seja válida para todos. ${ }^{42}$

necessariamente pouco eficientes, de uma perspectiva econômica" (VIEIRA, Oscar Vilhena. Supremocracia. Revista de Direito GV, São Paulo, v. 4, n. 2, pp. 441-463, jul./dez. 2008. p. 442. Disponível em: <http://www.scielo. $\mathrm{br} / \mathrm{pdf} / \mathrm{rdgv} / \mathrm{v} 4 \mathrm{n} 2 / \mathrm{a} 05 \mathrm{v} 4 \mathrm{n} 2 . \mathrm{pdf}>$. Acesso em 20 jul. 2019.).

38 MENDES, Conrado Hübner. Direitos fundamentais, separação de poderes e deliberação. São Paulo: Saraiva, 2011. p. 214.

39 MENDES, Conrado Hübner. Direitos fundamentais, separação de poderes e deliberação. São Paulo: Saraiva, 2011. p. 214.

40 O termo "separação de poderes", comumente empregado, merece ser analisado de forma crítica. Ao comentar o capítulo XI da célebre obra O espírito das leis, de Montesquieu, Simone Goyard-Fabre avalia que não há a defesa de uma estática separação de poderes, há antes uma "balança de poderes". Nas palavras de Goyard-Fabre (GOYARD-FABRE, Simone. Os princípios filosóficos do direito político moderno. São Paulo: Martins Fontes, 2002. p. 240-241): "Esse capítulo não elabora uma teoria, como se costuma repetir, da 'separação de poderes', mas da 'balança dos poderes'. Essa concepção cabe numa frase: 'Para que não se possa abusar do poder, é preciso que, pela disposição das coisas, o poder detenha o poder'. Dito de outra forma, e indispensável que 'as três espécies de poder: a potência legisladora, a potência executora das coisas que dependem do direito das gentes e a potência executora daquelas que dependem do direito civil' não fiquem concentradas nas mãos de um mesmo homem ou de um mesmo corpo; para evitar a confusão dos poderes que resultaria dessa concentração, os três poderes deem ser distribuídos a instâncias organicamente distintas e aptas, por sua cooperação, portanto por sua complementaridade, a exercer nas formas a autoridade do governo". Soma-se a isso, a ideia de que essa "balança de poderes" representaria uma "separação de funções" exercidas por meio do diálogo (SILVA, Sandoval Alves da. O Ministério Público e a concretização dos direitos humanos. Salvador: JusPodivm, 2016. p. 95-226; BRANDÃO, Rodrigo. Supremacia judicial versus diálogos constitucionais. 2. ed. Rio de Janeiro: Lumens Juris, 2017) e voltadas para um fim. Isso exige um trabalho conjunto tendo em vista a consecução do bem comum político, entendido como um bem que transcende as particularidades de cada indivíduo, sem, porém, negá-las. A comunidade política, fruto da pluralidade de opiniões e não da unidade delas, é mesmo assim capaz de deliberar para alcançar uma sinfonia e não uma homofonia, uma unidade que não nega a diversidade, mas permite, por meio do direito como instituição, buscar o "consenso do direito". As diferenças morais jamais serão eliminadas, porém é possível que as pessoas (plurais) possam agir como cidadãos (unidade), o que não suprime a pluralidade, mas conserva a busca do bem comum político (BARZOTTO, Luis Fernando. Teoria política. Porto Alegre: Livraria do Advogado, 2018. p. 93-94).

41 MENDES, Conrado Hübner. Direitos fundamentais, separação de poderes e deliberação. São Paulo: Saraiva, 2011. p. 213.

42 MENDES, Conrado Hübner. Una división de poderes deliberativa: entre el diálogo y la última palabra. In: GARGARELLA, Roberto (Org.). Por una justicia dialógica: el Poder Judicial como promotor de la deliberación democrática. 1. ed. Buenos Aires: Siglo Veintiuno, 2014. E-book. Não paginado. 
Pensa-se no Supremo Tribunal como a instituição responsável por decidir por último. Porém, é importante enfatizar, tomando como base a teoria dos diálogos institucionais, que o papel místico de atribuir ao Supremo Tribunal Federal a responsabilidade de "salvar a democracia contra a vontade de outros poderes" não se sustenta, podendo até se voltar contra a própria Corte, pois tende a resultar em uma prática decisória acanhada e tímida ou mesmo em uma reação mais agressiva do outro poder ${ }^{43}$. Assim, a definição de uma instituição política como democrática está mais no conteúdo das decisões do que propriamente em um critério de procedimento estipulado anteriormente, o que não quer dizer que a substância das decisões desconsidere o procedimento e dissolva a sua autoridade ${ }^{44}$.

O que se quer, com a teoria dialógica, é demonstrar que atribuir a um dos poderes toda a tarefa de dar unidade, uniformidade e integridade ao ordenamento jurídico, como se propõem as teorias apresentadas anteriormente sobre a eficácia vinculante dos precedentes, parece não ser a saída mais racional diante de um panorama mais deliberativo, no qual os poderes, apesar de desempenharem funções distintas, têm a mesma tarefa de promover a segurança jurídica e a proteção de direitos garantidos pela Constituição da República. ${ }^{45}$ Isto é, essas instituições têm tarefas a desempenhar de forma integrada e colaborativa, e não uma em contraposição à outra. A própria concepção da separação de poderes e, portanto, do modelo de freios e contrapesos revela um diálogo público, promovendo uma "transformação das preferências" e do debate entre os distintos ramos do poder. ${ }^{46}$

É nesse sentido que, embora se reconheça como cláusula pétrea o postulado da separação de poderes, isso não impede, de outro modo, que não se discuta o

\footnotetext{
43 MENDES, Conrado Hübner. Direitos fundamentais, separação de poderes e deliberação. São Paulo: Saraiva, 2011. p. 215.

44 MENDES, Conrado Hübner. Direitos fundamentais, separação de poderes e deliberação. São Paulo: Saraiva, 2011. p. 213.

45 Daí a se falar não mais na existência de um Poder com o monopólio da última palavra, mas, sim na construção de uma prática dialógica que possibilite a convivência do constitucionalismo com a democracia. Poderes independentes e harmônicos, justamente porque dotados desses qualificativos, devem ser capazes de aprimoramento contínuo e dialético a respeito de questões relevantes para o país. O Parlamento pode e deve participar da tarefa de interpretação da Constituição, como interlocutor privilegiado, dada a sua configuração de instância representativa da vontade popular para as deliberações políticas (BARBOSA, Antônio Ezequiel Inácio; LIMA, Martonio Mont'Alverne. Influência das teorias dos diálogos institucionais e da última palavra provisória no pensamento constitucional brasileiro contemporâneo. Revista de Investigações Constitucionais, Curitiba, v. 5, n. 109-128, jan./abril. 2018. Disponível em: <https://revistas.ufpr.br/rinc/article/view/55825>. Acesso em: 20 de julho de 2020, p. 120).

46 GARGARELLA, Roberto. El nuevo constitucionalismo dialógico frente al sistema de los frenos y contrapesos. In: GARGARELLA, Roberto (Org.). Por una justicia dialógica: el Poder Judicial como promotor de la deliberación democrática. Buenos Aires: Siglo Veintiuno, 2014. E-book. Não paginado.
} 
modo de exercício da jurisdição constitucional, com o objetivo de preservar o caráter democrático que deve "permear todas as manifestações do poder estatal em nosso país".47

Em razão disso, vê-se que essas finalidades, concebidas à primeira vista como sendo de responsabilidade apenas das cortes superiores, especialmente do Supremo Tribunal Federal, devem ser submetidas a uma análise que propõe um profundo empenho e uma profunda participação também do Poder Legislativo, de modo que se alcance êxito tanto na garantia dos direitos fundamentais, como na promoção do bem comum ${ }^{48}$.

Diante disso, a teoria dos diálogos institucionais contribui para a interpretação da Constituição da República a partir da superação da ideia de que cabe ao Supremo Tribunal Federal a última palavra sobre o sentido da Constituição. Propõe-se então um papel colaborativo para alcançar o melhor resultado interpretativo, além de se apresentar uma saída para as dualidades preestabelecidas. De fato, os critérios rígidos de atuação tendem a afastar a melhor atuação dos poderes, em vez de colocá-los juntos na busca de soluções mais racionais e céleres para os problemas complexos que se delineiam em sociedade.

47 BARBOSA, Antônio Ezequiel Inácio; LIMA, Martonio Mont'Alverne. Influência das teorias dos diálogos institucionais e da última palavra provisória no pensamento constitucional brasileiro contemporâneo. Revista de Investigações Constitucionais, Curitiba, v. 5, n. 109-128, jan./abril. 2018. Disponível em: <https://revistas.ufpr. br/rinc/article/view/55825>. Acesso em: 20 de julho de 2020, p. 113.

48 Com efeito, a formação, a apropriação e a partilha do bem comum ou coletivo têm assento numa ética de diálogo, de relacionamento horizontal entre pessoas e instituições. Esse diálogo abrange as necessidades humanas, a igualdade, a liberdade e uma concepção de justiça que envolve a concepção de Estado e a própria divisão de poderes públicos entre si e a relação entre eles e a sociedade. Para funcionarem eficazmente (em direção às finalidades estabelecidas pela Constituição, cujo valor último é a dignidade da pessoa humana), esses poderes devem ser analisados sob o enfoque do diálogo. Nessa colaboração dialógica, abandona-se a visão maniqueísta dos poderes (especialmente Legislativo e Judiciário). Com efeito, as teorias do diálogo não buscam a resposta sobre quem tem a última palavra, mas constroem o direito deliberando conjuntamente. Essa linha de pensamento jurídico tem o condão de contribuir para a eficácia do direito, pois direciona a sociedade para a maior participação cidadã nas decisões políticas, na deliberação prática (direta e indireta) sobre o bem comum. Isso se traduz na maior consciência e observação dos deveres fundamentais, no reconhecimento e na atenção respeitosa à pluralidade de pensamentos, valores e ações, nos laços de solidarismo social como valor de cidadania e na atuação colaborativa e dialógica dos poderes estatais, vistos como um sistema de integração e de cooperação para o trabalho em conjunto, com integração, harmonia e equilíbrio. Nas palavras de Silva, "[...] deve-se observar que os motivos de uma ação humana deliberativa também podem ser demonstrados pelo poder informacional. Obtém-se esse poder falando com pessoas, ensinando, explicando, argumentando, discutindo, perguntando, respondendo, por meio dos padrões existentes, com disposição para tornar o conhecimento acessível aos outros, pois as influências são mais duradouras quando se compreende, clara e logicamente, o 'que' e 'por que' se decide" (SILVA, Sandoval Alves da. O Ministério Público e a concretização dos direitos humanos. Salvador: Juspodivm, 2016. p. 203). Ainda sobre o bem comum, aduz Luis Fernando Barzotto: "O bem comum só pode ser conhecido mediante deliberação conjunta. Como ele é um bem complexo, que se altera conforme as condições em que se encontra, somente no debate racional é que seu conteúdo pode ser determinado caso a caso. A sua natureza impõe o método da sua busca. Se o bem comum é o bem de todos, todos devem participar na sua determinação. Em primeiro lugar, porque são os destinatários do bem, e o ponto de vista do destinatário não pode ser ignorado em um processo deliberativo. Em segundo lugar, porque a complexidade do bem comum exige sua análise do maior número possível dos pontos de vista" (BARZOTTO, Luis Fernando. A democracia na Constituição. São Leopoldo: Unisinos, 2005. p. 35-36). 
Não se objetiva descaracterizar a função de cada um dos poderes, objetiva-se antes mostrar que sua atuação deve estar voltada para o fim de garantir os direitos fundamentais sem que para isso haja necessidade de alçar um dos poderes ao papel de protagonista dessa efetivação, sendo a percepção gradual mais cabível quando se busca um ponto ou grau de equilíbrio entre os extremos ${ }^{49}$.

A atuação conjunta e deliberativa entre o Poder Judiciário e o Poder Legislativo, proposta pela teoria dos diálogos, permite-nos superar um modelo de judicial review forte, no qual a última palavra caberia ao Judiciário, em razão da sua suposta capacidade de melhor interpretar a Constituição. Essa assertiva representa a ideia de "Supremocracia" defendida por Oscar Vilhena Vieira, tanto no sentido de imposição das decisões do Supremo Tribunal Federal ao demais juízes e tribunais, quanto no sentido de expansão da autoridade do Supremo em detrimento dos demais poderes, cuja ideia é colocar a Corte no centro de nosso sistema político ${ }^{50}$.

A necessidade de superação dessa ideia ocorre, sobretudo, pela verificação de que uma ampla transferência de autoridade para o Judiciário e para as cortes constitucionais deve ser encarada não como algo progressivo e natural no desenvolvimento da democracia, mas como uma interação estratégica entre as elites que estão interessadas em se proteger da incerteza do futuro, o que é próprio da política democrática. ${ }^{51}$

Não há que se falar, portanto, do monopólio da última palavra, mas sim da construção de uma prática dialógica que possibilita a coexistência do constitucionalismo com a democracia. A interpretação da Constituição deve resultar de uma dialética contínua a respeito de questões relevantes para o país. ${ }^{52}$

Desse modo, pode-se analisar que a manutenção de uma ordem democrática requer um "olhar gradual" 53 , uma análise que não se encarregue de delegar a um dos poderes toda a função de garantir a proteção dos direitos, a segurança jurídica, a unida-

49 SILVA, Sandoval Alves da. O Ministério Público e a concretização dos direitos humanos. Salvador: Juspodivm, 2016. p. 95.

50 VIEIRA, Oscar Vilhena. Supremocracia. Revista de Direito GV, São Paulo, v. 4, n. 2, pp. 441-463, jul./dez. 2008. p. 443. Disponível em: <http://www.scielo.br/pdf/rdgv/v4n2/a05v4n2.pdf >. Acesso em 20 jul. 2019.

51 ARANTES, Rogério Bastos. Cortes constitucionais. In: AVRITZER, Leonardo; BIGNOTTO, Newton; FILGUEIRAS, Fernando; GUIMARÃES, Juarez; STARLING, Heloísa (Org.). Dimensões políticas da justiça. Rio de Janeiro: Civilização Brasileira, 2013. p. 198.

52 BARBOSA, Antônio Ezequiel Inácio; LIMA, Martonio Mont'Alverne. Influência das teorias dos diálogos institucionais e da última palavra provisória no pensamento constitucional brasileiro contemporâneo. Revista de Investigações Constitucionais, Curitiba, v. 5, n. 109-128, jan./abril. 2018. Disponível em: <https://revistas.ufpr. br/rinc/article/view/55825>. Acesso em: 20 de julho de 2020, p. 120.

53 "Com efeito, o raciocínio binário baseado em dicotomias abrangentes e rígidas deve ser superado pelo raciocínio gradualista que permite avaliar a medida de certa qualidade, o grau de realização de determinado ideal. O raciocínio gradualista não se preocupa em dizer se algo é ou não é, mas, antes, em que grau ou medida algo é ou não é, ou quanto algo se aproxima ou se distancia do ideal" (SILVA, Sandoval Alves da. O Ministério Público e a concretização dos direitos humanos. Salvador: Juspodivm, 2016. p. 96). 
de e a uniformidade do direito, sob pena de se reforçar a retórica do Supremo Tribunal Federal como "guardião entrincheirado" e também detentor da última palavra sobre a Constituição ${ }^{54}$.

Trata-se, assim, de possibilitar que os poderes desempenhem suas tarefas tendo em vista a concretização de direitos, mas sem se alçar à condição de poder absoluto para dar uma última solução para o caso, uma vez que tanto o Legislativo quanto o Judiciário podem instaurar diálogos com o objetivo de alcançar a segurança jurídica sem que isso vise paralisar a atuação dos outros poderes.

A teoria dos diálogos institucionais já tem sido referida, inclusive, pela própria Suprema Corte, o que demonstra uma mudança de racionalidade no que diz respeito à interação entre os poderes e à busca de uma melhor interpretação da Constituição. No caso da Ação Direta de Inconstitucionalidade (ADI) 5.105, o relator, Ministro Luiz Fux, que julgou o acesso proporcional a dois terços do tempo destinado à propaganda eleitoral gratuita aos novos partidos, ressaltou que o princípio fundamental da separação de poderes clama pela pluralização dos intérpretes da Constituição, com a atuação coordenada dos poderes estatais - Legislativo, Executivo e Judiciário -, juntamente com os outros segmentos da sociedade civil, os quais atuarão, cada um com suas capacidades específicas, para o aperfeiçoamento das instituições democráticas, sem a pretensão de serem os únicos e exclusivos intérpretes da Carta da República ${ }^{55}$.

Pode-se constatar que o modelo clássico da tripartição de poderes mostra-se insuficiente na resolução de problemas complexos que ultrapassem as fronteiras preestabelecidas de atuação, que, além de serem pouco práticas, são também indesejáveis ${ }^{56}$. Essa modificação da visão tradicional procura evidenciar pelo menos dois aspectos sobre a formulação de decisões em casos controversos. O primeiro deles enfatiza que decisões tomadas em qualquer um dos poderes podem ser contestadas em outras instâncias públicas porque passam a ter um caráter parcialmente definitivo. O outro aspecto diz respeito ao reconhecimento de que "cada espaço de poder possui características que o potencializam ou o inibem para a realização de tomada de decisões"57.

Nessa perspectiva, a defesa de uma eficácia vinculante a partir dos precedentes do Supremo Tribunal Federal parece buscar uma unidade do direito a qualquer custo,

\footnotetext{
54 MENDES, Conrado Hübner. Direitos fundamentais, separação de poderes e deliberação. São Paulo: Saraiva, 2011. p. 217.

55 BRASIL. Supremo Tribunal Federal. Ação Direta de Inconstitucionalidade no 5.105, Rel. Min. Luiz Fux, julgado em 01 out. 2015.

56 CLÈVE, Clèmerson Merlin; LORENZETTO, Bruno Meneses. Diálogos institucionais: estrutura e legitimidade. Revista de Investigações Constitucionais, Curitiba, v. 2, n. 3, pp. 183-206, set./dez. 2015. p. 189. Disponível em: <http://www.scielo.br/pdf/rinc/v2n3/2359-5639-rinc-02-03-0183.pdf>. Acesso em 25 set. 2019.

57 CLĖVE, Clèmerson Merlin; LORENZETTO, Bruno Meneses. Diálogos institucionais: estrutura e legitimidade. Revista de Investigações Constitucionais, Curitiba, v. 2, n. 3, pp. 183-206, set./dez. 2015. p. 189. Disponível em: <http://www.scielo.br/pdf/rinc/v2n3/2359-5639-rinc-02-03-0183.pdf>. Acesso em 25 set. 2019.
} 
vinculando os demais juízes e tribunais não em razão do conteúdo das decisões, mas apenas com base em um critério de autoridade institucional. Frise-se que, antes do CPC/2015, mesmo quando as decisões tinham um sentido diverso do pretendido pelo Legislativo, esse poder talvez optasse por não tentar alterar o posicionamento jurisprudencial, posto que os demais juízes e tribunais podiam - e isso muitas vezes acontecia - simplesmente adotar posicionamento diverso daquele fixado pelo Supremo Tribunal Federal ${ }^{58}$.

A teoria dos diálogos - e, assim, a afirmação de que não cabe ao STF a última palavra sobre a Constituição - é fundamental em um panorama de precedentes vinculantes, pois, em muitos casos, a modificação do entendimento jurisprudencial pelo Legislativo restará como a única saída ${ }^{59}$.

\section{A DIFICULDADE DE SUPERAÇÃO DOS PRECEDENTES E O PAPEL DO PODER LEGISLATIVO}

A proposição de precedentes vinculantes, conforme demonstrado, comporta inúmeras críticas, principalmente no que diz respeito à superação desses entendimentos firmados na Corte Suprema. Diante disso, debater-se-ão algumas formas de superação, apontando as suas dificuldades e demonstrando que, em alguns casos, apenas o Legislativo poderá superar algumas decisões, sob pena de engessamento de determinados entendimentos.

Assim, entre as inúmeras formas de judicial departures, o overruling é um dos casos de afastamento de uma regra jurisprudencial, o qual ocorre "quando o tribunal posterior adota uma nova norma concreta que decide um caso compreendido na hipótese de incidência de uma regra anterior de origem jurisprudencial"60. Embora seja apenas uma das espécies dos casos de afastamento de uma regra jurisprudencial, o overruling é especialmente importante porque não se refere apenas a um problema de aplicação de um precedente, ou seja, à não ocorrência de suas consequências no caso concreto, mas "representa uma ab-rogação da própria norma adscrita aceita como precedente" ${ }^{61}$.

Essa anulação de um precedente pelo próprio órgão que o estabeleceu, embora varie entre os sistemas jurídicos do civil law e do common law, seja por razões

\footnotetext{
58 PEIXOTO, Ravi. A teoria dos precedentes e a doutrina dos diálogos institucionais - em busca de um equilíbrio entre o Poder Legislativo e o Poder Judiciário. Civil Procedure Review, [s.I.], v. 9, n. 2, pp. 41-73, mai./ago. 2018. p. 44.

59 PEIXOTO, Ravi. A teoria dos precedentes e a doutrina dos diálogos institucionais - em busca de um equilíbrio entre o Poder Legislativo e o Poder Judiciário. Civil Procedure Review, [s.I.], v. 9, n. 2, pp. 41-73, mai./ago. 2018. p. 45.

60 BUSTAMANTE, Thomas da Rosa de. Teoria do precedente judicial: a justificação e a aplicação de regras jurisprudenciais. São Paulo: Noeses, 2012. p. 387.

61 BUSTAMANTE, Thomas da Rosa de. Teoria do precedente judicial: a justificação e a aplicação de regras jurisprudenciais. São Paulo: Noeses, 2012. p. 388.
} 
institucionais, seja por razões extrainstitucionais, as quais influenciam a força do precedente judicial, deve ser expressamente tematizada, levando-se em consideração o precedente que será afastado62.

A proposição de uma reorganização do Judiciário, como demonstrado anteriormente, dificulta o overruling, que, mesmo não sendo incompatível com um sistema de precedentes vinculantes, encontra grandes dificuldades para operar.

Exemplo dessa dificuldade é a alteração trazida pela Lei n. ${ }^{0} 13.256 / 2016$, porque o CPC/2015, originalmente, previa o fim do duplo juízo de admissibilidade aos recursos especiais e extraordinários, legitimando o acesso de todos eles aos tribunais superiores, aos quais cabia a realização do juízo de admissibilidade. Não obstante, a Lei n. ${ }^{\circ}$ 13.256/2016 promoveu alteração na redação do CPC, retornando com o duplo juízo de admissibilidade, estabelecendo, também, que, contra decisão de inadmissibilidade de recurso especial e extraordinário por contrariedade a precedente firmado em repercussão geral ou recursos repetitivos, o recurso cabível é o agravo interno ao próprio tribunal a quo, conforme disposição do artigo 1030, I, alíneas a e b, combinado com o parágrafo 2. ${ }^{\circ}$, do CPC/2015. Somado a isso, o artigo 1042, caput, do CPC/2015 previu que o agravo em recurso extraordinário (RE) ou em recurso especial (REsp), interposto contra a decisão do presidente ou vice-presidente, que inadmitir RE ou REsp não é cabível quando o fundamento da decisão for a aplicação de entendimento firmado em regime de repercussão geral ou em julgamento de recursos repetitivos ${ }^{63}$.

Observa-se que esse modelo torna difícil a modificação de entendimentos firmados nos tribunais superiores, impedindo uma necessária rediscussão desses precedentes a partir da alteração de situações fáticas ou jurídicas. É nesse ponto que se propôs a controversa utilização da reclamação constitucional como meio de superação de precedentes. Controversa porque, embora parte da doutrina reconheça a impossibilidade de utilização da reclamação para fins de superação dos precedentes por falta de previsão legal ${ }^{64}$ e utilização diversa do que se pretende - instrumento para garantia e reforço da autoridade das decisões -, há autores que sustentam a possibilidade de seu manejo nos casos de inadmissão dos recursos especial e extraordinário e de improvimento do agravo interno, sendo a reclamação, talvez, a única possibilidade de modificação dos precedentes firmados pelas cortes superiores.

\footnotetext{
62 BUSTAMANTE, Thomas da Rosa de. Teoria do precedente judicial: a justificação e a aplicação de regras jurisprudenciais. São Paulo: Noeses, 2012. p. 388.

63 NUNES, Dierle; FREITAS, Mariana de Carvalho. O STJ e a necessidade de meios para superação dos precedentes. Revista Consultor Jurídico, São Paulo, 22 nov. 2017. Disponível em: <https://www.conjur.com.br/ 2017-nov-22/opiniao-stj-meios-superacao-precedentes>. Acesso em 25 set. 2019.

64 Dierle Nunes é representante dessa corrente, defendendo também o cabimento de novo recurso especial ou de novo recurso extraordinário contra a decisão de não provimento do agravo interno, como maneira de ter acesso ao tribunal superior e, sobretudo, de garantir aos jurisdicionados o direito de suscitar argumentos para a superação dos precedentes.
} 
Nessa perspectiva, um ordenamento jurídico que busque a efetiva participação dos sujeitos processuais na formação e, também, na superação dos julgados, quando não mais atendam às relações sociais e às mudanças culturais, não deve admitir o engessamento das decisões e sua aplicação mecânica, sob pena de não concretizar um modelo constitucional de processo, utilizando os precedentes judiciais de forma não democrática.

Insiste-se em uma valorização da análise do panorama macroestrutural estatal, buscando-se soluções técnicas que sejam adequadas aos avanços ocorridos após a Segunda Guerra e que desaguam em nosso país após 1988. Tendo isso como pressuposto, deve-se tematizar e entender que a concepção teórica de um modelo de processo constitucional democrático busca uma democratização processual mediante a problematização de conceitos como liberalismo, socialização e pseudossocialização processual, propondo, assim, o resgate do papel constitucional do processo como estrutura formadora das decisões judiciais, sendo essas decisões fruto de uma interação comparticipativa e policêntrica ${ }^{65}$.

Esse modelo comparticipativo busca garantir julgados mais robustamente fundamentados, que visem julgar melhor para julgar menos e sejam capazes de abordar todos os fundamentos favoráveis ou contrários, com contraditório amplo, com participação de amici curiae, oitiva de argumentos em audiências públicas, assim como a observância de um dever de congruência entre o que se determinou (preparou) para o julgamento e o que se realmente julgou. Isso "poderá levar a uma efetiva redução do retrabalho e, inclusive, diminuição da litigiosidade pela existência de uma efetiva opinião da corte sobre o caso", de maneira a verificar o que pretende o art. 926 do CPC, uma jurisprudência coerente, íntegra e estável ${ }^{66}$, de maneira a verificar o que pretende o artigo 926 do CPC, uma jurisprudência coerente, íntegra e estável.

Assim, um modelo de processo constitucional democrático preza pelo diálogo, pela interação dos poderes, o que vai muito além de um modelo adversarial e de quem tem a última palavra sobre a Constituição. A importância de se debaterem as dificuldades da superação dos precedentes e os melhores meios para que isso se concretize está tanto na manutenção e no fortalecimento do processo constitucional democrático, como nas soluções gradualmente mais adequadas para cada momento histórico, social e cultural.

65 NUNES, Dierle; BAHIA, Alexandre. Processo, jurisdição e processualismo constitucional democrático na América Latina: alguns apontamentos. Revista Brasileira de Estudos Políticos, Belo Horizonte, n. 101, jul./dez. 2010. p. 83.

66 VIANA, Aurélio; NUNES, Dierle. Precedentes: a mutação do ônus argumentativo. Rio de Janeiro: Forense, 2018. p. 388. 
É certo que, diante do que foi debatido, não se pode recorrer a soluções simplistas para problemas complexos por meio da blindagem das cortes superiores, que não devem ser incomodadas com novos argumentos que as levem a mudar os precedentes já firmados.

Nessa perspectiva, não se pode descuidar do importante papel do Poder Legislativo, inclusive na superação dos precedentes judiciais, de modo que a interação dos poderes deve objetivar a melhor interpretação da Constituição para a solução dos problemas sociais. É importante que se entenda, assim, que tanto o Legislativo quanto o Judiciário possuem fins específicos, mas ambos buscam a promoção de uma gradual segurança jurídica por meio da coerência e da integridade do ordenamento jurídico.

Pressupor que ambos os poderes buscam essas finalidades permite-nos conceber a superação de um modelo adversarial por meio de um modelo de diálogo, sendo este último uma evidente "saída intermediária e conciliatória que comporta dois componentes centrais: o desenho institucional e a cultura política. O modelo ideal é o de deliberação institucional dialógica, e não o modelo adversarial67".

A adoção da perspectiva dialógica possibilita sobrelevar a típica visão idealizada de privilégio de um poder sobre o outro, porque, embora o Parlamento tenha maior capacidade institucional para a concretização de políticas públicas e o Judiciário, maior capacidade institucional para a aplicação de direitos fundamentais, o que lhes confere uma prioridade na concretização das normas constitucionais, disso não deve advir que, em razão da capacidade institucional, a interpretação de cada poder será necessariamente a melhor sobre determinada matéria, mas, antes, que provavelmente o será ${ }^{6}$.

O modelo dos diálogos possibilita evidenciar os mecanismos de controle recíproco entre os poderes, sujeitando o exercício das funções típicas por um "poder" a constante controle pelos outros, não sendo possível garantir uma maior capacidade institucional de um agente para proferir a melhor interpretação. A proposta é a mudança de compreensão de direitos fundamentais e políticas públicas como áreas exclusivas de atuação do Judiciário e do Legislativo (respectivamente) para uma compreensão que considere apenas a prevalência prima facie dos "poderes" nessas esferas, permitindo-se um controle permanente do adequado desempenho da sua função típica ${ }^{69}$.

Assim, é nessa perspectiva que se analisarão os casos em que o Poder Legislativo superou os precedentes do Supremo Tribunal Federal, evitando a eternização de

\footnotetext{
67 SILVA, Sandoval Alves da. O Ministério Público e a concretização dos direitos humanos. Salvador: Juspodivm, 2016. p. 185-186.

68 BRANDÃO, Rodrigo. Supremacia judicial versus diálogos constitucionais. 2. ed. Rio de Janeiro: Lumens Juris, 2017. p. 295.

69 BRANDÃO, Rodrigo. Supremacia judicial versus diálogos constitucionais. 2. ed. Rio de Janeiro: Lumens Juris, 2017. p. 295-296.
} 
decisões que produzam efeitos práticos permanentes e permitindo que a interação prática entre Legislativo e Judiciário ocorra a partir da contribuição da capacidade institucional de cada um $^{70}$.

Desse modo, sustentar que a eficácia vinculante dos precedentes esteja voltada exclusivamente às cortes supremas como responsáveis por dar unidade ao direito e uniformidade às decisões judiciais, parece desconsiderar a possibilidade de superação desses entendimentos pelo Poder Legislativo nos casos de divergência interpretativa.

A teoria dos diálogos institucionais reconhece, então, que os atores institucionais possuem falhas e virtudes específicas e que, mediante a interação entre todos eles, seria possível a construção mais qualificada de um processo deliberativo, sendo o propósito dessa teoria a minimização de erros pelo refinamento das razões públicas pelas Cortes e pelo Legislativo. Esse refinamento possibilitaria a busca de melhores soluções para os problemas apresentados, em vez da limitação ao Poder Judiciário ou ao Poder Legislativo $^{71}$.

Enfrentar a possibilidade de superação legislativa é entender que a construção de respostas para os casos apresentados acontecerá pelo contínuo diálogo entre os poderes, buscando-se encontrar soluções mais justas a partir do reconhecimento da finalidade comum das instituições.

\section{ANÁLISE DO CASO DA VAQUEJADA À LUZ DA TEORIA DOS DIÁ- LOGOS CONSTITUCIONAIS}

Neste tópico, abandonaremos um aspecto apenas conceitual para demonstrar os casos em que o Legislativo procedeu à superação de precedentes do STF, por meio da edição de leis ordinárias que superaram entendimentos anteriormente estabelecidos pela Corte.

Essa interação do Poder Judiciário com o Legislativo é também potencializada pela arquitetura da Constituição de 1988, que trouxe no seu bojo uma larga determinação de políticas públicas ${ }^{72}$, o que resultou na clara relação entre decisões judiciais sobre direitos fundamentais e modificação dessas políticas públicas, as quais podem ou não ser aceitas pelo Poder Legislativo, levando-o, no caso de discordância, a superar os precedentes firmados pelo Supremo Tribunal Federal. Assim, o reconhecimento de

70 BRANDÃO, Rodrigo. Supremacia judicial versus diálogos constitucionais. 2. ed. Rio de Janeiro: Lumens Juris, 2017. p. 296.

71 PEIXOTO, Ravi. A teoria dos precedentes e a doutrina dos diálogos institucionais - em busca de um equilíbrio entre o Poder Legislativo e o Poder Judiciário. Civil Procedure Review, [s.l.], v. 9, n. 2, pp. 41-73, mai./ago. 2018. p. 50.

72 ARANTES, Rogério Bastos; COUTO, Cláudio Gonçalves. Construção democrática e modelos de Constituição. Revista de Ciências Sociais, Rio de Janeiro, v. 53, n. 3, p. 545-585, 2010. Disponível em: <https://bdpi.usp. br/bitstream/handle/BDPI/6840/art_ARANTES_Construcao_democratica_e_modelos_de_Constituicao_2010. pdf; jsessionid=9C49C3346087824812270EA502C21FBA? sequence=1>. Acesso em: 4 abr. 2019. 
direitos fundamentais na Constituição da República, colocou o Poder Judiciário, em especial o Supremo Tribunal Federal em papel de destaque, de maneira que é necessário observar a relação entre poderes a partir de um novo viés, não mais pautado na ideia de supremacia de um poder em relação aos demais, mas adotando-se uma postura que envolve o diálogo entre eles ${ }^{73}$. E observe-se que não é apenas no caso de discordância dos precedentes firmados que o Legislativo poderá proceder à sua superação, isso também é possível nos casos de modificação das situações fáticas e jurídicas.

Nesse sentido, havendo grande dificuldade ou até impossibilidade de superação dos precedentes pelas técnicas processuais, como demonstrado no tópico anterior, é possível que o Legislativo seja a única opção, o que não representa uma supremacia legislativa, uma vez que, no caso de edição de lei ordinária, o Judiciário pode controlar a constitucionalidade da norma que reverteu a sua decisão anterior, e a "'superação normativa' não representará a última palavra sobre a controvérsia constitucional"74.

Assim é o caso da Lei n. ${ }^{\circ}$ 15.299/2013 do Estado do Ceará75, que regulamentava a vaquejada naquele Estado, determinando as regras para a sua realização. Após promulgada, o Ministério Público Federal, na pessoa de seu Procurador Geral da República, propôs a Ação Direta de Inconstitucionalidade n. ${ }^{\circ}$ 4.983/CE contra a referida lei, alegando violação do artigo 225, § 1. , VII, da Constituição da República, pois o torneio traria graves e irreparáveis prejuízos à fauna, uma vez que os animais eram submetidos a maus-tratos e a situações degradantes.

O Supremo Tribunal Federal decidiu, na ADI n. ${ }^{\circ} 4.983 / \mathrm{CE}^{76}$, pela inconstitucionalidade da Lei n. ${ }^{\circ}$ 15.299/2013 do Ceará, com efeitos erga omnes naquele Estado, aceitando o argumento de que a prática da vaquejada submete os animais à crueldade. Assim, foi decidido que, naquele caso específico, devia-se proteger prioritariamente a fauna, em detrimento do pleno exercício das manifestações culturais, inscrito no artigo 225 , 1. ${ }^{\circ}$, da Constituição da República.

Após essa decisão, entidades de proteção de animais questionaram a mesma prática da vaquejada em Teresina, no Estado do Piauí, a qual foi mantida pelo juízo.

\footnotetext{
73 LEAL, Mônia Clarissa Henning; MORAES, Maria Valentina. "Diálogo" entre Poderes no Brasil? Da inconstitucionalidade da regulação da vaquejada à vaquejada como patrimônio cultural imaterial brasileiro: uma análise crítica. Revista de Investigações Constitucionais, Curitiba, v. 5, n. 1, p. 63-81, jan./abril. 2018. Disponível em: < https://revistas.ufpr.br/rinc/article/view/55825>. Acesso em: 20 de julho de 2020, p.75-76.

74 BRANDÃO, Rodrigo. Supremacia judicial versus diálogos constitucionais. 2. ed. Rio de Janeiro: Lumens Juris, 2017. p. 286.

75 ESTADO DO CEARÁ. Lei n. $15.299 / 2013$, de 8 de janeiro de 2013. Regulamenta a vaquejada como prática desportiva e cultural no Estado do Ceará. Diário Oficial do Estado, Fortaleza, série 3, ano V, n. 10, p. 15, 15 jan. 2013. Disponível em: <https://belt.al.ce.gov.br/index.php/legislacao-do-ceara/organizacao-tematica/cultura-e-esportes/item/2582-lei-n-15-299-de-08-01-13-d-o-15-01-13>. Acesso em: 20 set. 2019.

76 BRASIL. Supremo Tribunal Federal. Ação Direta de Inconstitucionalidade no 4.983, Rel. Min. Marco Aurélio, publicado em 16 mai. 2019. Disponível em: <http://portal.stf.jus.br/processos/detalhe.asp?incidente $=4425243>$. Acesso em 20 set. 2019.
} 
Em razão disso, foi ajuizada no Supremo Tribunal Federal a Reclamação Constitucional n. ${ }^{\circ} 25.869$, alegando o descumprimento da decisão daquele órgão, com base na ADI n. ${ }^{\circ}$ 4.983/CE. Todavia, o Supremo Tribunal Federal julgou improcedente a reclamação, alegando que a decisão na ADI produziu efeito erga omnes somente no Estado do Ceará e naquele caso concreto, já que a apuração da presença de maus-tratos aos animais deu-se somente em relação à vaquejada praticada naquele Estado.

Posteriormente, o Congresso Nacional editou a Lei n. ${ }^{0} 13.364 / 2016^{77}$, prevendo a vaquejada como patrimônio cultural imaterial, e, em seguida, a Emenda Constitucional (EC) n. ${ }^{\circ} 96 / 2017^{78}$, que incluiu o $\S 7 .^{\circ}$ do artigo 225 da Constituição Federal. A referida EC superou o entendimento firmado pela Suprema Corte no caso da vaquejada do Estado do Ceará, uma vez que acrescentou um parágrafo ao artigo 215 da Constituição da República, para explicar que as atividades desportivas não são tidas como cruéis caso sejam consideradas patrimônio cultural imaterial. O objetivo é evitar uma futura proibição em qualquer estado da federação.

Ainda, em setembro de 2019, foi sancionada a Lei n. ${ }^{0} 13.873 / 2019^{79}$, que, alterando a Lei n. ${ }^{0} 13.364 / 2016$, inclui o laço, bem como as respectivas expressões artísticas e esportivas, como manifestação cultural nacional, além de elevar essas atividades à condição de bem de natureza imaterial integrante do patrimônio cultural brasileiro e dispor sobre as modalidades esportivas equestres tradicionais e sobre a proteção ao bem-estar animal.

Observe-se que não se trata de questão pacificada, existindo a ADI n. ${ }^{\circ} 5.728$ ajuizada pelo Fórum Nacional de Proteção e Defesa Animal contra a EC n. 9 96/2017. Não obstante, a análise proposta é a superação de um precedente firmado pelo Supremo Tribunal Federal acerca da inconstitucionalidade da Lei n. ${ }^{\circ}$ 15.299/2013 do Estado do Ceará, por meio da Lei n. ${ }^{\circ} 13.364 / 2016$ e da EC n. ${ }^{\circ}$ 96/2017, assim como pela Lei n. ${ }^{\circ}$ $13.873 / 2019$.

Dessa forma, é importante destacar que não se defende uma "supremacia do Congresso" como uma reação a uma "supremacia judicial", defende-se, antes, um modelo dialógico para articular de forma mais proveitosa o autogoverno do povo e também dos direitos fundamentais, para que se promova, por intermédio dos múltiplos

77 BRASIL. Lei n. ${ }^{\circ}$ 13.364, de 29 de novembro de 2016. Eleva o Rodeio, a Vaquejada, bem como as respectivas expressões artístico-culturais, à condição de manifestação cultural nacional e de patrimônio cultural imaterial. Diário Oficial da União, Brasília, DF, Seção 1, p. 1, 30 nov. 2016. Disponível em: <https://www2.camara.leg.br/ legin/fed/lei/2016/lei-13364-29-novembro-2016-783953-norma-pl.html>. Acesso em: 22 set. 2019.

78 BRASIL. Emenda Constitucional n. ${ }^{\circ}$ 96, de 6 de julho de 2017. Acrescenta $§ 7.0^{\circ}$ ao art. 225 da Constituição Federal para determinar que práticas desportivas que utilizem animais não são consideradas cruéis, nas condições que especifica. Diário Oficial da União, Brasília, DF, 7 jun. 2017. Disponível em: <http://www.planalto. gov.br/ccivil_03/constituicao/Emendas/Emc/emc96.htm>. Acesso em: 20 set. 2019.

79 BRASIL. Lei n. ${ }^{\circ} 13.873$, de 17 de setembro de 2019. Altera a Lei n. 13.364 , de 29 de novembro de 2016, para incluir o laço, bem como as respectivas expressões artísticas e esportivas, como manifestação cultural nacional. Diário Oficial da União, Brasília, DF, Seção 1, p. 3, 18 set. 2019. Disponível em: <https://www2.camara.leg.br/ legin/fed/lei/2019/lei-13873-17-setembro-2019-789120-norma-pl.html>. Acesso em: 2 out. 2019. 
acessos aos interessados em determinada questão constitucional, um pluralismo da democracia, além de reduzir a possiblidade de uma decisão unilateral dos poderes. Essa possibilidade dinâmica do desempenho dos poderes da República em um modelo de "circularidade procedimental" 80 possibilita que a concretização da Constituição seja fruto de um processo interativo, com a participação e a contribuição dos poderes com seus conhecimentos específicos, o que torna a decisão mais qualificada e melhor, sobretudo quando se vislumbra um panorama de questões complexas. Assim, a teoria dos diálogos constitucionais conduz a interpretações constitucionais com resultados provisórios, que estão sujeitos permanentemente a críticas da esfera pública, situação que Ihes confere a possibilidade de autocorreção de acordo com uma prática de democracia deliberativa ${ }^{81}$.

A partir dessa análise, propõe-se rever o modelo de precedentes obrigatórios proposto pelas teorias apresentadas, pois a defesa de uma reestruturação do Poder Judiciário em Cortes de Precedentes, cujo objetivo precípuo é a fixação de teses para a sua posterior aplicação, encontra forte resistência quando se concebe a teoria dos diálogos, sobretudo no que diz respeito à possiblidade de superação dos precedentes vinculantes formados.

Nessa perspectiva, objetiva-se sedimentar o entendimento de que não cabe a um único poder a tarefa de dar unidade e racionalidade ao ordenamento jurídico, sendo uma tarefa participativa de todos, em um claro modelo de um processo constitucional democrático.

\section{CONCLUSÃO}

A teoria dos precedentes vinculantes enfrenta inúmeros desafios no Brasil. Trata-se de assumir a importante contribuição que a teoria dos precedentes pode trazer ao ordenamento jurídico brasileiro, ao invés de não admitir que a sua aplicação seja possível à realidade do civil law, sobretudo após a superação desse modelo dual entre esse modelo e o common law. Deve-se atentar, assim, à importância do diálogo entre o Poder Judiciário e o Poder Legislativo para a consecução de decisões que sejam mais adequadas e coerentes em um modelo de processo constitucional democrático.

Assim, buscar saídas graduais, que representem um diálogo entre a atuação dos poderes Legislativo e Judiciário, é entender que ambos, mesmo que desempenhem suas tarefas específicas, devem estar voltados para a única finalidade de garantir direitos fundamentais, seja por meio da criação de leis, seja por meio da melhor aplicação das leis ao caso concreto.

80 BRANDÃO, Rodrigo. Supremacia judicial versus diálogos constitucionais. 2. ed. Rio de Janeiro: Lumens Juris, 2017. p. 289.

81 BRANDÃO, Rodrigo. Supremacia judicial versus diálogos constitucionais. 2. ed. Rio de Janeiro: Lumens Juris, 2017. p. 289. 
Não há um entendimento estanque, uma fotografia que mereça representar a decisão final sobre uma situação complexa, há uma longa construção de decisões que possibilitem a interação democrática entre os diversos poderes da República.

Dedicar a um desses poderes toda a tarefa de representação democrática, bem como impor ao outro uma tarefa contramajoritária, é reforçar uma atividade adversarial e pouco dialógica, e que pouco pode contribuir para a realização de uma melhor interpretação da Constituição.

A possibilidade de superação de um precedente pelo Poder Legislativo, como demonstrado com o caso da Vaquejada, permite compreender as dificuldades práticas das teorias que defendem uma reestruturação do Poder Judiciário para a fixação de uma Corte de Precedentes, responsável por garantir a unidade interpretativa do direito.

Desse modo, vincular todas as decisões do Supremo Tribunal Federal como precedentes normativos capazes de garantir a gradual uniformidade, a integridade, a coerência e a segurança jurídica ao ordenamento jurídico brasileiro é outorgar-lhe um ônus que talvez o Judiciário não possa cumprir.

\section{REFERÊNCIAS}

ARANTES, Rogério Bastos. Cortes constitucionais. In: AVRITZER, Leonardo; BIGNOTTO, Newton; FILGUEIRAS, Fernando; GUIMARÃES, Juarez; STARLING, Heloísa (Org.). Dimensões políticas da justiça. Rio de Janeiro: Civilização Brasileira, 2013.

ARANTES, Rogério Bastos; COUTO, Cláudio Gonçalves. Construção democrática e modelos de Constituição. Revista de Ciências Sociais, Rio de Janeiro, v. 53, n. 3, pp. 545-585, 2010. Disponível em: <https://bdpi.usp.br/bitstream/handle/BDPI/6840/art_ARANTES_Construcao_democratica_e_modelos_de_Constituicao_2010.pdf;jsessionid=9C49C3346087824812270EA502C21FBA?sequence $=1>$. Acesso em 4 abr. 2019.

BARBOSA, Antônio Ezequiel Inácio; LIMA, Martonio Mont'Alverne. Influência das teorias dos diálogos institucionais e da última palavra provisória no pensamento constitucional brasileiro contemporâneo. Revista de Investigações Constitucionais, Curitiba, v. 5, n. 109-128, jan./abril. 2018.

BARZOTTO, Luis Fernando. A democracia na Constituição. São Leopoldo: Unisinos, 2005.

BARZOTTO, Luis Fernando. Teoria política. Porto Alegre: Livraria do Advogado, 2018.

BRANDÃO, Rodrigo. Supremacia judicial versus diálogos constitucionais. 2. ed. Rio de Janeiro: Lumens Juris, 2017.

BRASIL. Emenda Constitucional n 96, de 6 de julho de 2017. Acrescenta $\S 7 .^{\circ}$ ao art. 225 da Constituição Federal para determinar que práticas desportivas que utilizem animais não são consideradas cruéis, nas condições que especifica. Diário Oficial da União, Brasília, DF, 7 jun. 2017. Disponível em: <http://www.planalto.gov.br/ccivil_03/constituicao/Emendas/Emc/emc96.html>. Acesso em 20 set. 2019. 
BRASIL. Lei no 13.364, de 29 de novembro de 2016. Eleva o Rodeio, a Vaquejada, bem como as respectivas expressões artístico-culturais, à condição de manifestação cultural nacional e de patrimônio cultural imaterial. Diário Oficial da União, Brasília, DF, Seção 1, p. 1, 30 nov. 2016. Disponível em: <https://www2.camara.leg.br/legin/fed/lei/2016/lei-13364-29-novembro-2016783953-norma-pl.html>. Acesso em: 22 set. 2019.

BRASIL. Lei no 13.873, de 17 de setembro de 2019. Altera a Lei n. ${ }^{\circ} 13.364$, de 29 de novembro de 2016, para incluir o laço, bem como as respectivas expressões artísticas e esportivas, como manifestação cultural nacional. Diário Oficial da União, Brasília, DF, Seção 1, p. 3, 18 set. 2019. Disponível em: <https://www2.camara.leg.br/legin/fed/lei/2019/lei-13873-17-setembro-2019789120-norma-pl.html>. Acesso em: 2 out. 2019.

BRASIL. Supremo Tribunal Federal. Ação Direta de Inconstitucionalidade no 4.983, Rel. Min. Marco Aurélio, publicado em 16 mai. 2019. Disponível em: <http://portal.stf.jus.br/processos/detalhe.asp?incidente=4425243>. Acesso em 20 set. 2019.

BRASIL. Supremo Tribunal Federal. Ação Direta de Inconstitucionalidade n 5.105, Rel. Min. Luiz Fux, julgado em 01 out. 2015.

BUSTAMANTE, Thomas da Rosa de. Teoria do precedente judicial: a justificação e a aplicação de regras jurisprudenciais. São Paulo: Noeses, 2012.

CÂMARA, Alexandre Freitas. Levando os padrões decisórios a sério. São Paulo: Atlas, 2018.

CLÈVE, Clèmerson Merlin; LORENZETTO, Bruno Meneses. Diálogos institucionais: estrutura e legitimidade. Revista de Investigações Constitucionais, Curitiba, v. 2, n. 3, pp. 183-206, set./ dez. 2015. Disponível em: <http://www.scielo.br/pdf/rinc/v2n3/2359-5639-rinc-02-03-0183.pdf>. Acesso em 25 set. 2019.

DIDIER JR., Fredie. Sistema brasileiro de precedentes judiciais obrigatórios e os deveres institucionais dos tribunais: uniformidade, estabilidade, integridade e coerência da jurisprudência. In: DIDIER JR., Fredie; CUNHA, Leonardo Carneiro da; ATAÍDE JR.; MACÊDO, Lucas Buril de. Precedentes. Salvador: Juspodivm, 2015.

ESTADO DO CEARÁ. Lei n. $15.299 / 2013$, de 8 de janeiro de 2013. Regulamenta a vaquejada como prática desportiva e cultural no Estado do Ceará. Diário Oficial do Estado, Fortaleza, série 3, ano V, n. 10, p. 15, 15 jan. 2013. Disponível em: <https://belt.al.ce.gov.br/index.php/legislacao-do-ceara/ organizacao-tematica/cultura-e-esportes/item/2582-lei-n-15-299-de-08-01-13-d-o-15-01-13>. Acesso em 20 set. 2019.

GARGARELLA, Roberto. El nuevo constitucionalismo dialógico frente al sistema de los frenos y contrapesos. In: GARGARELLA, Roberto (Org.). Por una justicia dialógica: el Poder Judicial como promotor de la deliberación democrática. Buenos Aires: Siglo Veintiuno, 2014.

GOYARD-FABRE, Simone. Os princípios filosóficos do direito político moderno. São Paulo: Martins Fontes, 2002. 
KLAFKE, Guilherme Forma; PRETZEL, Bruna Romano. Processo decisório no Supremo Tribunal Federal: aprofundando o diagnóstico das onze ilhas. Revista de Estudos Empíricos em Direito, [s.l.], v. 1, n. 1, p. 89-104, jan. 2013.

LEAL, Mônia Clarissa Henning; MORAES, Maria Valentina. "Diálogo" entre Poderes no Brasil? Da inconstitucionalidade da regulação da vaquejada à vaquejada como patrimônio cultural imaterial brasileiro: uma análise crítica. Revista de Investigações Constitucionais, Curitiba, v. 5, n. 1, p. 63-81, jan./abril. 2018.

MAGALHÃES, Breno Baía; SILVA, Sandoval Alves da. O grau de vinculação dos precedentes à luz do STF: o efeito vinculante é absoluto? In: ANJOS FILHO, Robério Nunes dos (Org). Direitos humanos e direitos fundamentais: diálogos contemporâneos. Salvador: Juspodivm, 2013.

MARINONI, Luiz Guilherme. Precedentes obrigatórios. 5. ed. rev., atual. e ampl. São Paulo: Revista dos Tribunais, 2016.

MARINONI, Luiz Guilherme; ARENHART, Sérgio Cruz; MITIDIERO, Daniel. Novo Curso de Processo Civil. Vol. 1. 4. ed. São Paulo: Revista dos Tribunais, 2019.

MENDES, Conrado Hübner. Direitos fundamentais, separação de poderes e deliberação. São Paulo: Saraiva, 2011.

MENDES, Conrado Hübner. Una división de poderes deliberativa: entre el diálogo y la última palabra. In: GARGARELLA, Roberto (Org.). Por una justicia dialógica: el Poder Judicial como promotor de la deliberación democrática. 1. ed. Buenos Aires: Siglo Veintiuno, 2014.

MITIDIERO, Daniel. Precedentes: da persuasão à vinculação. São Paulo: Revista dos Tribunais, 2016.

NERY JUNIOR, Nelson; NERY, Rosa Maria de Andrade. Comentários ao Código de Processo Civil. São Paulo: Revista dos Tribunais, 2015.

NUNES, Dierle; BAHIA, Alexandre. Processo, jurisdição e processualismo constitucional democrático na América Latina: alguns apontamentos. Revista Brasileira de Estudos Políticos, Belo Horizonte, n. 101, jul./dez. 2010.

NUNES, Dierle; FREITAS, Mariana de Carvalho. O STJ e a necessidade de meios para superação dos precedentes. Revista Consultor Jurídico, São Paulo, 22 nov. 2017. Disponível em: <https://www. conjur.com.br/2017-nov-22/opiniao-stj-meios-superacao-precedentes>. Acesso em 25 set. 2019.

PEIXOTO, Ravi. A teoria dos precedentes e a doutrina dos diálogos institucionais - em busca de um equilíbrio entre o Poder Legislativo e o Poder Judiciário. Civil Procedure Review, [s.I.], v. 9, n. 2, pp. 41-73, mai./ago. 2018.

SILVA, Sandoval Alves da. O Ministério Público e a concretização dos direitos humanos. Salvador: Juspodivm, 2016. 
SILVA, Virgílio Afonso da. "Um voto qualquer?" O papel do ministro relator na deliberação no Supremo Tribunal Federal. Revista Estudos Institucionais, Rio de Janeiro, v. 1, n. 1, pp. 180-200, 2015.

SILVA, Virgílio Afonso da. Do We Deliberate? If So, How? European Journal of Legal Studies, Florence, v. 9, n. 2, pp. 209-240, 2017.

STRECK, Lenio Luiz. Precedentes judiciais e hermenêutica: o sentido da vinculação no CPC/2015. Salvador: Juspodivim, 2018.

VERBICARO, Loiane Prado. Judicialização da política, ativismo e discricionariedade judicial. 2. ed. rev. e ampl. Rio de Janeiro: Lumen Juris, 2019.

VIANA, Aurélio; NUNES, Dierle. Precedentes: a mutação do ônus argumentativo. Rio de Janeiro: Forense, 2018.

VIEIRA, Oscar Vilhena. Supremocracia. Revista de Direito GV, São Paulo, v. 4, n. 2, pp. 441-463, jul./dez. 2008. Disponível em: <http://www.scielo.br/pdf/rdgv/v4n2/a05v4n2.pdf>. Acesso em 20 jul. 2019.

VOJVODIC, Adriana de Moraes; MACHADO, Ana Mara França; COSTA, Evorah Lusci. Escrevendo um romance, primeiro capítulo: precedentes e processo decisório no STF. Revista Direito GV, São Paulo, v. 5, n. 1, pp. 21-44, jan./jun. 2009.

ZANETI JR., Hermes. O valor vinculante dos precedentes: teoria dos precedentes normativos formalmente vinculantes. 4. ed. rev., atual e ampl. Salvador: Juspodivm, 2019. 